\title{
Effect of Androstenedione on Adipogenesis in Murine C3H10T1/2 Mesenchymal Cells
}

\author{
Pandurangan Ramaraj1 ${ }^{*}$, Jorge N. Artaza ${ }^{2}$, Indrani Sinha-Hikim², Wayne E. Taylor ${ }^{2,3}$ \\ ${ }^{1}$ Department of Biochemistry, Kirksville College of Osteopathic Medicine, A.T. Still University of Health Sciences, \\ Kirksville, MO, USA \\ ${ }^{2}$ Division of Endocrinology, Charles R. Drew University of Medicine and Science, Los Angeles, CA, USA \\ ${ }^{3}$ Department of Health and Life Sciences, Charles R. Drew University of Medicine and Science, Los Angeles, CA, \\ USA \\ Email: ${ }^{*}$ pramaraj@atsu.edu
}

Received 19 January 2015; accepted 4 February 2015; published 9 February 2015

Copyright (C) 2015 by authors and Scientific Research Publishing Inc.

This work is licensed under the Creative Commons Attribution International License (CC BY).

http://creativecommons.org/licenses/by/4.0/

(c) (i) Open Access

\begin{abstract}
Clinical trials of weak androgen androstenedione (AD) administered at a high concentration, showed an increase in muscle mass in men like strong androgens testosterone $(T)$ and dihydrotestosterone (DHT), but did not show any inhibitory effect on fat mass unlike strong androgens. This observation prompted us to check the in-vitro effect of AD on adipogenesis using mouse mesenchymal multipotent cells (C3H10T1/2), which can differentiate into both myoblasts and adipocytes. Results indicated that $A D$ inhibited adipogenesis at $10 \mathrm{nM}, 100 \mathrm{nM}$ and $1 \mu \mathrm{M}$ concentrations, but not at $10 \mu \mathrm{M}$ concentration. AD did not inhibit adipogenesis at $10 \mu \mathrm{M}$ concentration and also did not inhibitmyogenesis at $10 \mu \mathrm{M}$ concentration. Addition of bicalutamide, an androgen receptor (AR) antagonist decreased myogenesis and increased adipogenesis, indicating that the effect of AD was mediated through AR. Another weak androgen dehydroepiandrosterone (DHEA) also showed the same pattern of adipogenesis in 10T1/2 cells. AD also showed a similar pattern of adipogenesis in 3T3-L1 preadipocyte cells. Thus, the in-vitro results of AD on adipogenesis correlated with the in-vivo results of $A D$ on fat-mass from clinical trials and suggested a possible difference in biological action between weak androgens (AD, DHEA) and strong androgens (T, DHT) on adipogenesis. Since the biological action of $A D$ was mediated through $A R$, this physiological difference onadipogenesis could be due to the nature (partial agonist/antagonist) of AD binding to AR.
\end{abstract}

\section{Keywords}

Androstenedione, Adipogenesis, Myogenesis, Androgen Receptor, Bicalutamide

${ }^{*}$ Corresponding author.

How to cite this paper: Ramaraj, P., Artaza, J.N., Sinha-Hikim, I. and Taylor, W.E. (2015) Effect of Androstenedione on Adipogenesis in Murine С3H10T1/2 Mesenchymal Cells. Open Journal of Endocrine and Metabolic Diseases, 5, 9-18.

http://dx.doi.org/10.4236/ojemd.2015.52002 


\section{Introduction}

Androgens such as testosterone (T) and dihydrotestosterone (DHT) have a powerful anabolic effect in determining body composition by increasing lean body mass and decreasing fat mass [1]-[10]. Since these anabolic steroids have been abused by athletes and body builders [11], they cannot be legally used without prescription [12]. Androgens such as androstenedione (AD) and dehydroepiandrosterone (DHEA) are considered to be weak androgens. DHEA is the precursor of androstenedione [13], which is further converted to testosterone [14] [15] and estrogen. Androstenedione was also defined legally in 2005 as a regulated anabolic steroid [16]. Androstenedione possessed many essential properties of androgens. It's bound to the ligand binding domain of androgen receptor (AR) though with a lower affinity than T or DHT. Like strong androgens, AD also induced AR nuclear translocation and promoted myogenic differentiation of mouse mesenchymal multipotent (10T1/2) cells [17]. The pro-myogenic effects of androstenedione were blocked by bicalutamide, an AR antagonist, indicating that these effects were mediated through an AR dependent pathway [17].

Administration of $\delta 4$-androstenedione to hypogonadal men for twelve weeks at a high dose of $1500 \mathrm{mg}$ per day was associated with an increase in fat free mass and significant gains in muscle strength [17]. However, androstenedione administration to hypogonadal men was not associated with significant reduction in whole body fat mass [17]. Moreover, plasma estradiol and estrone levels were increased during androstenedione administration. The above finding that fat mass was not decreased in vivo by high dose of AD led us to check the effect of increasing concentration of androstenedione on adipogenesis in C3H10T1/2 cell cultures. C3H10T1/2 cells were used previously to study the effect of strong androgens $\mathrm{T}$ and DHT on myogenesis and adipogenesis, as C3H10T1/2 cells can differentiate into myoblasts and adipocytes depending upon the culture conditions [18][20]. As expected initially, there was a decrease in adipogenesis up to $1 \mu \mathrm{M}$ concentration. But, at $10 \mu \mathrm{M}$ concentration, AD did not inhibit adipogenesis and it was back to the control level. This unexpected lack of adipogenic inhibition at $10 \mu \mathrm{M}$ concentration of $\mathrm{AD}$ was reproduced by another weak androgen DHEA $(10 \mu \mathrm{M})$ in 10T1/2 cells and was also observed in pre-adipocyte 3T3-L1 cells treated with AD, suggesting a possible difference in biological action between weak and strong androgens on adipogenesis.

\section{Materials and Methods}

Hormones $\delta 4$-androstene 3, 17-dione (AD), testosterone (T), dihydrotestosterone (DHT) and estrogen $\left(\mathrm{E}_{2}\right)$ were all purchased from Sigma Chemical Co., St Louis, MO. Culture medium DMEM, fetal bovine serum (FBS) and Trypsin were purchased from Fisher Scientific Co.

\subsection{Cell Culture Methods}

Mouse $10 \mathrm{~T} 1 / 2$ cells grown at $37^{\circ} \mathrm{C}$ in DMEM with $10 \% \mathrm{FBS}, 4 \mathrm{mM}$ glutamine, and $1 \mathrm{x}$ antibiotic-antimycotic (GM) were treated with $20 \mu \mathrm{M}$ 5-azacytidine (aza) in GM. After 3 days, cells were split 1:2 and were allowed to recover in GM for 2 days. Cells were seeded at 70\% confluence in 6-well plates or chamber slides and grown with test agents for 0 to14 days [17].

Mouse 3T3-L1 preadipocytes (American Type Culture Collection, Manassas, VA) were maintained in growth medium (GM) containing DMEM supplemented with 10\% FBS as described previously [21]. Differentiation was induced in 100\% confluent 3T3-L1 cells by incubating them in adipogenic medium (AM) (GM with 0.5 $\mathrm{mM}$ isobutylmethylxanthine, $1 \mu \mathrm{M}$ dexamethasone and $10 \mu \mathrm{g} / \mathrm{ml}$ insulin) for three days with or without androgens. This was followed by changing the medium to GM containing $10 \mu \mathrm{g} / \mathrm{ml}$ insulin with or without androgens at various concentrations for another 2 days and then to GM plus treatments for up to 10 days.

\subsection{Immunohistochemistry}

For immunochemical analyses, cells grown in chamber slides were fixed in 2\% paraformaldehyde for 20 min, quenched with $\mathrm{H}_{2} \mathrm{O}_{2}$, blocked with normal horse serum and incubated with anti-myosin heavy chain II (MHCII) antibody [20]. Detection was based on a secondary biotinylated antibody, followed by the addition of streptavidin-horseradish peroxidase ABC complex (1:100) (Vectastain Elite ABC System, Novocastra Laboratories, Newcastle upon Tyne, UK) and 3,3-diaminobenzidine. The cells were counter-stained with Meyer's hematoxyline. 


\subsection{Oil Red 0 Staining}

Cells were fixed in 2\% paraformaldehyde after treatments and stained with $0.3 \%$ Oil Red O (Sigma Chemical Co., Saint Louis, MO) for $15 \mathrm{~min}$ as described [22]. For quantitative analysis of Oil Red O retention in these cells, stained adipocytes were extracted with $1 \mathrm{ml}$ of 4\% Igepal CA-630 (Sigma) in isopropanol and absorbance was measured by spectrophotometry at $520 \mathrm{~nm}$.

\subsection{Western Blot Analysis}

Cell lysates (equal aliquots of 50 - $100 \mu \mathrm{g}$ ) in lysis buffer (20 mM Tris-HCl, pH 7.8, 0.5\% SDS containing protease inhibitors) were subjected to Western blot analyses [20] by 7.5\% - 12\% SDS-PAGE, transferred to PVDF membrane by electroblotting and analyzed by immunodetection using anti-myosin heavy chain II (MHCII) antibody (1:300 dilution) (Santa Cruz Biotechnology, Santa Cruz, CA). Washed filters were incubated with 1:2000 dilution of secondary antibody of goat anti-rabbit IgG linked to horseradish peroxidase. Immuno-reactive bands were visualized using the ECL detection system (Amersham Biosciences, Piscataway, NJ).

\subsection{Reverse Transcription-PCR}

Total RNA was extracted from cell cultures by using Trizol-reagent (Invitrogen, Carlsbad, CA) and was purified and characterized by measuring at $\mathrm{A}_{260}$. Two micrograms aliquot of total RNA was reversely transcribed and the resulting cDNA was amplified for 35 PCR cycles by melting at $94^{\circ} \mathrm{C}$ for $30 \mathrm{sec}$, primer annealing at $58^{\circ} \mathrm{C}$ for 30 sec and extension at $72^{\circ} \mathrm{C}$ for $1 \mathrm{~min}$. PCR products were analyzed by electrophoresis in $1.5 \%$ agarose gel using ethidium bromide staining (20). The locations of DNA sequences for the forward/reverse PCR primers are as follows: C/EBP $\alpha$ (225 bp), 843-864/1067-1047 on NM_007678; and GAPDH (152 bp) 606-626/758-738 on BC023196.

\subsection{Statistical Analysis}

Data are presented as mean \pm SEM. Pair-wise comparisons between groups were performed using Student's T-test. All comparisons were two-tailed and $\mathrm{P}$ value less than 0.05 were considered statistically significant. The experiments were repeated a minimum of two times for consistency and representative cell pictures from experiments are shown.

\section{Results}

\subsection{Effect of AD on Adipogenesis}

Initially the effect of AD on adipogenesis was studied using 10T1/2 cells induced to differentiate with 5-azacytidine and then treated with or without DHT or with alcohol vehicle which served as control. AD was added in a dose-dependent manner to 10T1/2 cells during differentiation of adipocytes. With increasing AD concentrations, a dose-dependent decrease in adipocyte numbers were seen in $10 \mathrm{nM}, 100 \mathrm{nM}$ and $1 \mu \mathrm{M}$ similar to the inhibition observed with $10 \mathrm{nM}$ DHT. However, at high concentration of $10 \mu \mathrm{M}$, suppression of adipogenesis was relieved back to the control level, as shown in the representative photomicrographs (Figure 1(a)). This biphasic effect on adipogenesis was also correlated quantitatively by counting Oil Red O stained adipocytes in wells (Figure 1(b)) and also by RT-PCR for C/EBP $\alpha$ expression. Analysis of mRNA for the key adipogenic transcription factor $\mathrm{C} / \mathrm{EBP} \alpha$ by RT-PCR again showed inhibition of gene expression at $1 \mu \mathrm{M}$ AD, but relief from inhibition at the higher $10 \mu \mathrm{M}$ concentration of AD (Figure $1(\mathrm{c})$ ).

\subsection{Reversal of AD Inhibition of Adipogenesis by AR Antagonist Bicalutamide}

Biphasic effect on adipogenesis suggested that the action of AD could be mediated through androgen receptor (AR). So, adipogenic experiment was repeated with $\mathrm{AD}$ along with androgen receptor antagonist bicalutamide. When cells were incubated with $300 \mathrm{nM}$ AD along with increasing concentrations of bicalutamide (Bic) up to 1 $\mu \mathrm{M}$, there was a dose dependent increase in fat cells as shown in the representative stained fat cell pictures (Figure 2(a)). This increase in fat cell numbers was correlated by counting Oil Red O stained adipocytes in wells (Figure 2(b)) at the cellular level and by RT-PCR for key adipogenic marker C/EBP $\alpha$ expression 


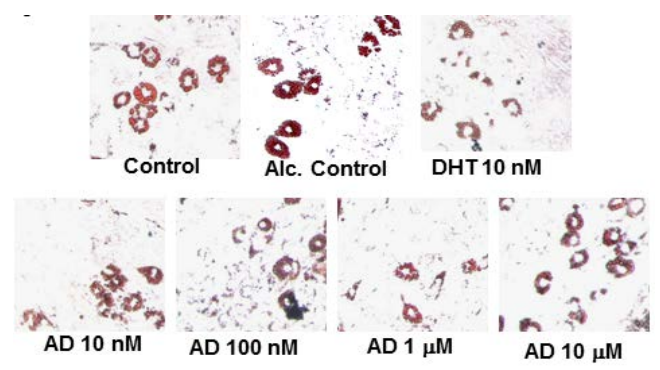

(a)

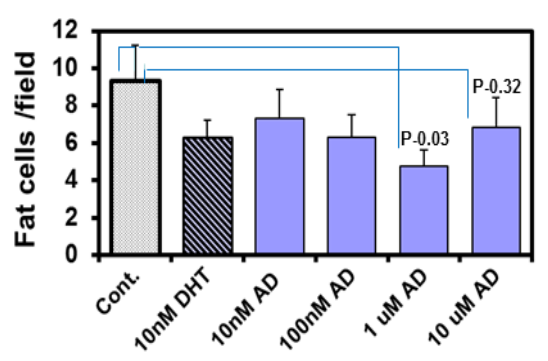

(b)

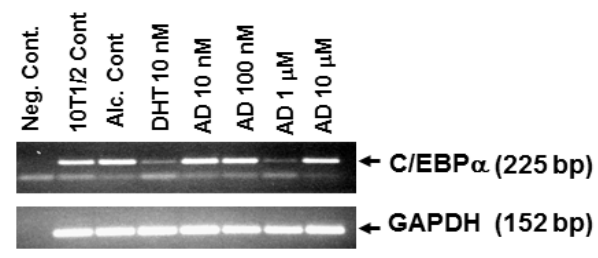

(c)

Figure 1. Effect of AD on adipogenesis. (a) Decrease in adipogenesis was seen up to $1 \mu \mathrm{M}$ of $\mathrm{AD}$. However, at $10 \mu \mathrm{M}$ concentration, inhibition was relieved and adipocytes were back to the control level as shown by the representative pictures of Oil Red O stained adipocytes. (b) Oil Red O stained cells were counted in 21 to 22 microscopic fields and expressed as average fat cell counts per field. Quantitation of stained fat cells also showed a decrease in adipocytes upto $1 \mu \mathrm{M}$ and then an increase at $10 \mu \mathrm{M}$ concentration of $\mathrm{AD}$. Pair-wise comparison between control and $1 \mu \mathrm{M}$ of $\mathrm{AD}$ showed a statistical significance with a P value of 0.03 . However the $\mathrm{P}$ value between control and $\mathrm{AD} 10 \mu \mathrm{M}$ was 0.3 , indicating there was no statistical significance as adipogenesis at $10 \mu \mathrm{M}$ concentration of AD was similar to the adipogenesis of the control cells. (c) Total RNA from adipocytes was characterized by carrying out RT-PCR for adipogenic marker C/EBP $\alpha$ expression along with house-keeping gene glyceraldehyde-3-phosphate dehydrogenase (GAPDH) expression, as described in Methods.

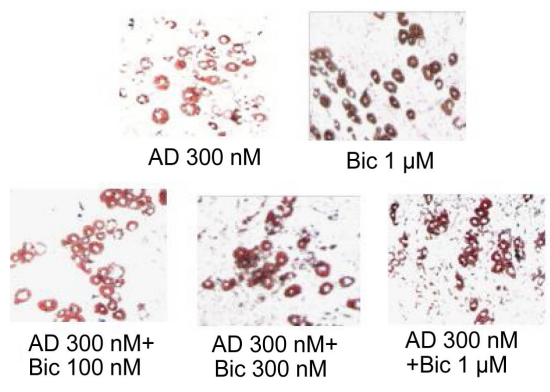

(a)

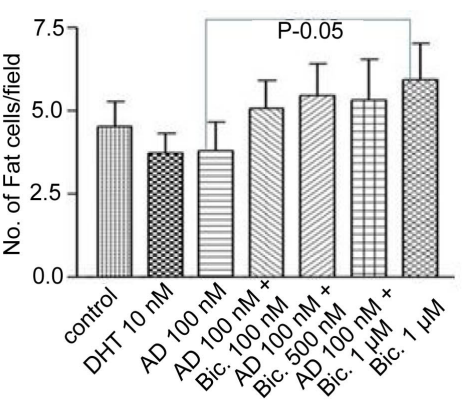

(b)

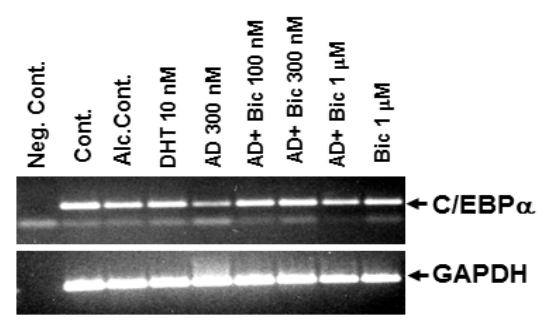

(c)

Figure 2. Reversal of AD inhibition of adipogenesis by AR antagonist bicalutamide. (a) Co-incbuation experiment of AD with bicalutamide showed an increase in fat cells with increasing concentrations of bicalutamide, as shown in the representative pictures of Oil Red O stained fat cells. (b) Oil Red O stained cells were counted in 21 to 22 microscopic fields and expressed as average fat cell counts per field. Results showed there was adose-dependent increase in adipocytes with increasing concentrations of bicalutamide, indicating that the effect of $\mathrm{AD}$ was mediated through androgen receptor. Pair-wise comparison of AD $100 \mathrm{nM}$ treated cells with BIC $1 \mu \mathrm{M}$ treated cells showed a P value of 0.05 , indicating a statistical significance in adipogenesis between the two treatment conditions. (c) Adipocytes were characterized by RT-PCR of total RNA for expression of adipogenic marker C/EBP $\alpha$ along with control GAPDH gene. 
(Figure 2(c)) at the molecular level. Experiments indicated AD biphasic effect on adipogenesis was mediated through AR. So, lack of suppression of adipogenesis seen at $10 \mu \mathrm{M}$ concentration of AD had to do with AD binding to AR. In fact, Chen et al. [23] showed a partial agonist/antagonist nature of AD binding to AR, based on cell transcription assay.

\subsection{Effect of AD and Bicalutamide on Myogenesis}

Since $10 \mu \mathrm{M}$ concentration of AD did not inhibit adipogenesis as expected for an androgen, we checked the effect of $\mathrm{AD}$ on myogenesis with increasing concentrations up to the high $10 \mu \mathrm{M}$ concentration of AD. Myogenesis was increased in a dose dependent manner even at the highest $(10 \mu \mathrm{M})$ concentration of AD. This was confirmed by immunostaining for the key myotube protein myosin heavy chain II (MHCII) at the cellular level and by Western blot for MHCII protein at the molecular level (Figure 3(a)). This experiment was repeated with the addition of increasing concentrations of bicalutamide along with $300 \mathrm{nM} \mathrm{AD}$. Bicalutamide addition decreased myogenesis drastically as confirmed by immunostaining for MHCII protein at the cellular and by Western blot at the protein level (Figure 3(b)). Androgen receptor antagonist bicalutamide substantially blocked the formation of myotubes at $1 \mu \mathrm{M}$ concentration.

\subsection{Comparison of Myogenesis and Adipogenesis in the Presence of AD \& Bicalutamide and Quantitation of Adipogenesis with AD, DHEA in 10T1/2 Cells and with AD in 3T3-L1 Cells}

Above observation led to the comparison of myogenesis and adipogenesis at $10 \mu \mathrm{M}$ concentration of $\mathrm{AD}$. At 10 $\mu \mathrm{M}$ concentration of $\mathrm{AD}$, myogenesis was increased, but adipogenesis was not suppressed as expected for an androgen (Figure 4(a)). But, if androstenedione (300 nM) was incubated with bicalutamide $(1 \mu \mathrm{M})$, myogenesis was suppressed, whereas adipogenesis was not suppressed (Figure 4(b)). This stands to reason, because AD action was mediated through AR and when AR was blocked, myogenesis was suppressed and adipogenesis was not suppressed again pointing to the role of AD binding to AR. We resorted to colorimetric method for quantitation of fat cells not only to remove any error crept in due to manual counting of stained fat cells, but also to compare quantitatively adipogenesis by another weak androgen and also adipogenesis in another adipogenic cell line. For colorimetric quantitation, Oil Red O stained fat cells were extracted with isopropanol containing Igepal and absorption was read at $520 \mathrm{~nm}$. There was suppression of adipogenesis at $10 \mathrm{nM}, 100 \mathrm{nM}$ and $1 \mu \mathrm{M}$ concentrations of $\mathrm{AD}$, but not at $10 \mu \mathrm{M}$ concentration of $\mathrm{AD}$ (Figure 4(c)). We repeated adipogenic experiment in 10T1/2 cells with another weak androgen DHEA to check whether this biphasic effect on adipogenesis was due to a spurious effect of $\mathrm{AD}$ or due to a common effect of weak androgens. Colorimetric quantitation of fat cells showed the same pattern of adipogenesis with DHEA. Inhibition of adipogenesis at $10 \mathrm{nM}, 100 \mathrm{nM}$ and $1 \mu \mathrm{M}$ of DHEA and a reversal back to the control level of adipogenesis at $10 \mu \mathrm{M}$ concentration of DHEA (Figure 4(c)), indicating it was a common effect of weak androgen on adipogenesis in C3H10T1/2 cells. As a follow-up of the above experiment, we tested the effect of AD on adipogenesis in another adipogenic cell line, the well-studied preadipocyte 3T3-L1 cells [21]. Adipogenesis was quantitated by colorimetric measurement. There was suppression of adipogenesis at $1 \mu \mathrm{M}$ of $\mathrm{AD}$ and non-suppression at $10 \mu \mathrm{M}$ of AD (Figure 4(d)). In 3T3-L1 cell line also a reversal back to the control level was reproducibly observed at high concentration $(10 \mu \mathrm{M})$ of $\mathrm{AD}$. So AD was unable to suppress adipogenesis at high concentration in another adipogenic (3T3-L1) cell line, which was shown to have AR [21]. Thus, indicating that the biphasic effect was an inherent biological effect of weak androgen $\mathrm{AD}$ on adipogenesis.

\subsection{Effect of Aromatase Inhibitor on Adipogenesis and Myogenesis}

Since AD was a metabolic precursor to $\mathrm{T}$, it was expected that $\mathrm{T}$ could increase myogenesis and decrease adipogenesis. However, $T$ can also be converted to estrogen $\left(E_{2}\right)$ by the enzyme aromatase. In the clinical experiment treating humans with $\mathrm{AD}$, there were increases in estrone and estradiol levels [17]. So we reasoned that at $10 \mu \mathrm{M}$ concentration of $\mathrm{AD}$, the increase in estrone and estradiol might be contributing to the increase in adipogenesis in C3H10T1/2 cells. Hence, we used aromatase enzyme inhibitor (AI) to block endogenous estrogen production in the cell. We carried out adipogenic experiments in the presence of $\mathrm{AD}$ and $\mathrm{AD}+\mathrm{AI}$. There was no significant difference in adipogenesis between cells treated with AD or with AD + AI (Figure 5(a)). So estrogen 


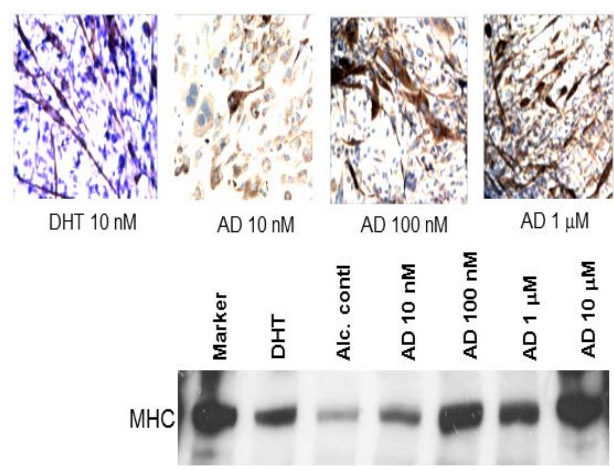

(a)
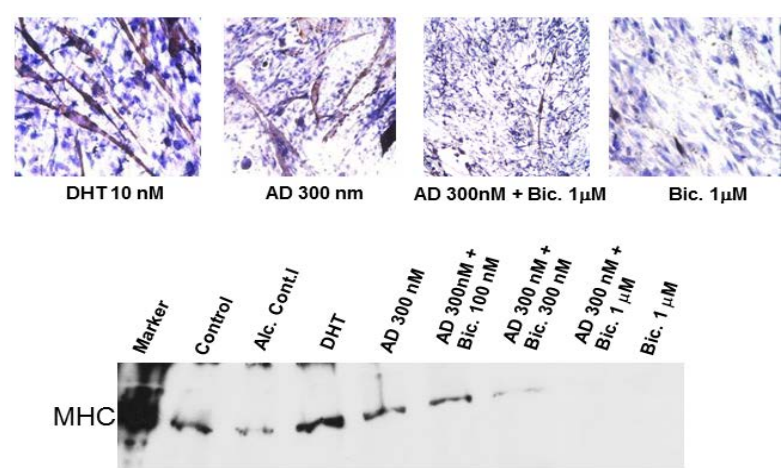

(b)

Figure 3. Effect of $\mathrm{AD}$ and bicalutamide co-incubation on myogenesis. (a) The observation that there was decrease in adipogenesis up to $1 \mu \mathrm{M}$ followed by no decrease inadipogensis at $10 \mu \mathrm{M}$ concentration of $\mathrm{AD}$, prompted us to check $\mathrm{AD}$ effect onmyogenesis by staining for myogenic marker myosin heavy chain II (MHCII) protein. As shown in the picture, myogenesis was increasedwith increasing concentrations of $\mathrm{AD}$ and correlated with the quantity of MHCII protein by western blot. (b) As expected AR antagonist bicalutamide inhibited AD induced myogenesis in a dose-dependent manner with a drastic inhibition in myogenesis seen at AD $300 \mathrm{nM}+$ bicalutamide $1 \mu \mathrm{M}$. This was confirmed by immunohistochemical staining and by western blot for MHCII protein.

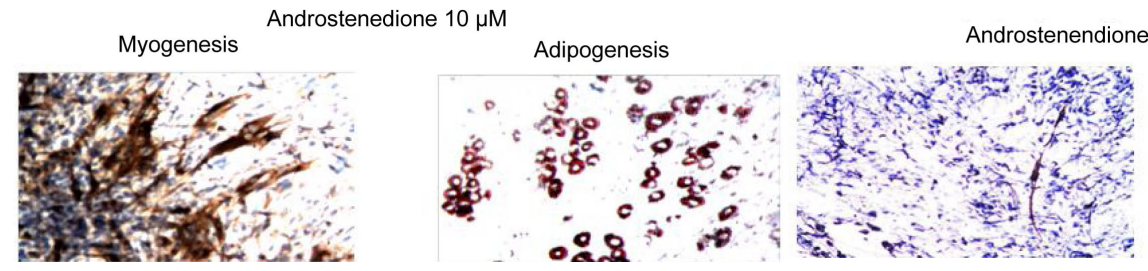

(a)

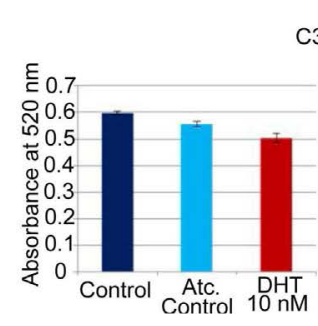

C3H10T1/2 cells

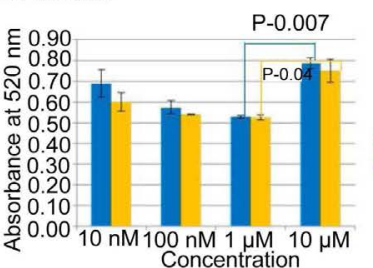

(c)
Quantitation of $\mathrm{F}$ at cells
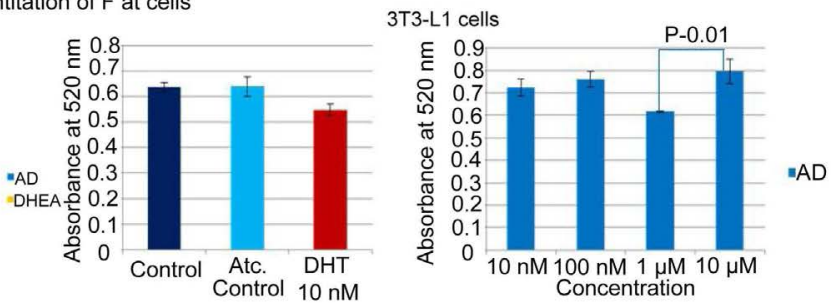

(d)

Figure 4. Comparison of myogenesis and adipogenesis in the presence of AD \& bicalutamide and quantitation of adipogenesis with AD, DHEA in 10T1/2 cells and with AD in 3T3-L1 cells. (a) At $10 \mu \mathrm{M}$ concentration of AD, myogenesis was increased, and adipogenesis was also increased as shown by celluar staining form myogenesis and adipogenesis. (b) AR antagonist bicalutamide was able to drastically inhibit AD induced myogenesis at $1 \mu \mathrm{M}$ concentration. As expected there was an increase in adipogenesis, indicating AD action was mediated through AR. (c) Quantitation of adipogenesis by AD and by another weak androgen DHEA in 10T1/2 cells showed a dose-dependent inhibition of adipogenesis up to $1 \mu \mathrm{M}$ and reversal back to control level of adipogenesis at $10 \mu \mathrm{M}$ concentration. Pair-wise comparison of adipogenesis between $1 \mu \mathrm{M}$ of $\mathrm{AD}$ and $10 \mu \mathrm{M}$ of $\mathrm{AD}$ showed a statistical significance with a P value of 0.007 . Similarly the pair-wise comparison between DHEA $1 \mu \mathrm{M}$ and $10 \mu \mathrm{M}$ showed a statistical significance with a P value of 0.04. (d) Quantitation of adipogenesis by AD in 3T3-L1 cells showed a decrease in adipogenesis at $1 \mu \mathrm{M}$ and reversal to control level of adipogenesis at $10 \mu \mathrm{M}$ concentration reproducing the same pattern of adipogenesis in 10T1/2 cells. Pair-wise comparison of adipogenesis between $1 \mu \mathrm{M}$ and $10 \mu \mathrm{M}$ of $\mathrm{AD}$ showed a statistical significance with a $\mathrm{P}$ value of 0.01 .

had no action on adipogenesis in 10T1/2 cells. In fact when estrogen was added directly to 10T1/2 cells, there was no increase in adipogenesis compared to untreated control cells. In order to make sure that the lack of increase inadipogenesis in the treated cells was not due to an increase in myogenesis mediated by AI, we also checked myogenesis by immunohistochemical staining for MHCII protein in myotubes. Again there were no appreciable differences in myogenesis between $\mathrm{AD}$ treated cells and $\mathrm{AD}+\mathrm{AI}$ treated cells (Figure 5(b)). By 


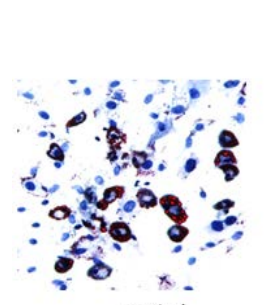

control

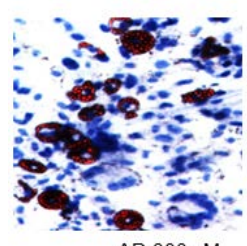

AD $300 \mathrm{nM}$
$A D+A l-A d i p o g e n e s i s$
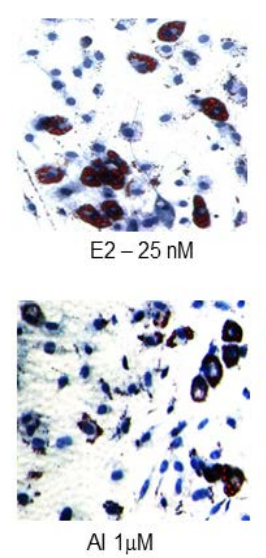

(a)

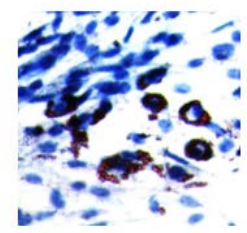

DHT $10 \mathrm{nM}$

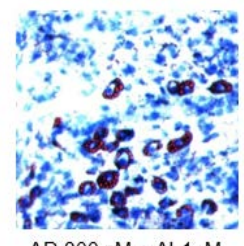

AD $300 \mathrm{nM}+\mathrm{Al} 1 \mu \mathrm{M}$

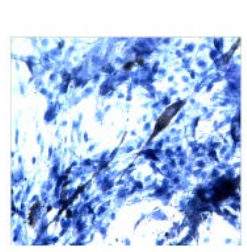

Control

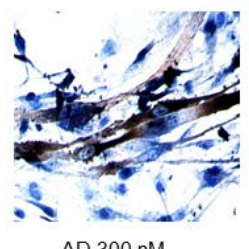

AD $300 \mathrm{nM}$
$A D+A l-M y o g e n e s i s$

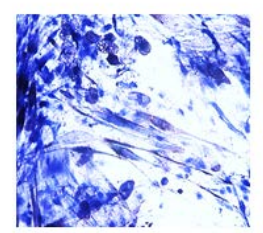

E2 - $25 \mathrm{nM}$

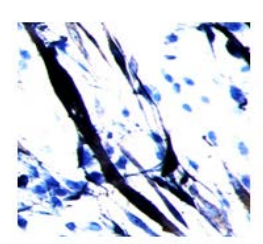

Al $1 \mu \mathrm{M}$

(b)

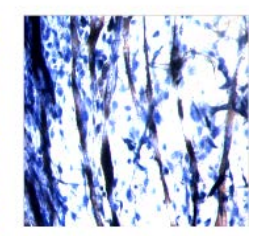

DHT $10 \mathrm{nM}$

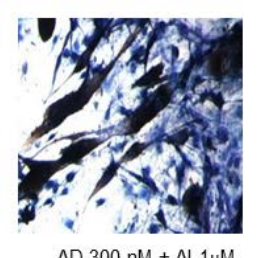

AD $300 \mathrm{nM}+\mathrm{Al} 1 \mu \mathrm{M}$

Figure 5. Effect of AI on adipogenesis and myogenesis in 10T1/2 cells. (a) AI inhibits aromatase enzyme which converts androstenedione to estrogen. With increase in concentrations of AI, there was no decrease in adipogenesis, implying estrogen had no role in the increased adipogenesis seen in AD treatment. Infact direct addition of estrogen ( $25 \mathrm{nM})$ did not show any increase in adipogenesis over the untreated control cells further strengthening the results of AI experiment. (b) Since AI did not show any effect on adipogenesis, the effect of AI on myogenesis was checked. AI did not have any effect on the regulation of myogenesis as shown by immunohistochemical staining of MHCII protein between AD treated cells and AD + AI treated cells.

these control experiments, the role of estrogen contributing to adipogenesis or AI contributing to myogenesis was ruled out. So, the increase back to the control level of adipogenesis at $10 \mu \mathrm{M}$ of $\mathrm{AD}$ was not due to estrogen, but due to AD only.

\section{Discussion}

Even though AD is classified as a weak androgen, at the cellular level it has biological effects similar to that of strong androgen testosterone and for this reason AD was banned as an over-the-counter natural supplement [16]. Androstenedione effects on myogenesis in 10T1/2 cells was already published [17], but its effect on adipogenesis in 10T1/2 cells was not known. In this paper, we examined the effect of increasing concentrations of AD on adipogenesis in 10T1/2 cells. AD suppressed adipogenesis up to $1 \mu \mathrm{M}$ concentration. But at high $10 \mu \mathrm{M}$ concentration, $\mathrm{AD}$ was not able to suppress adipogenesis and adipocyte numbers were back to the control level, showing a biphasic dose-response. This type of biphasic regulation by a sex steroid (androstenedione) was not unusual, as biphasic regulation of cell proliferation had already been reported for estrogen in MCF-7 breast cancer cell line [24] and for androgen in LNCaP prostate cancer cell line [25] [26]. When adipogenic experiments were repeated in the presence of AR antagonist bicalutamide, there was a decrease in myogenesis and increase in adipogenesis in a dose-dependent manner, indicating that AD action was mediated through AR. Morphological changes in cells either with $\mathrm{AD}$ or $\mathrm{AD}$ with bicalutamide were correlated for adipocytes at the molecular level with the expression of $\mathrm{C} / \mathrm{EBP} \alpha$, a key adipogenic marker and for myotubes by western blot and immunohistochemical staining of myosin heavy chain II (MHCII) protein, a key myogenic marker.

Oil Red O was used not only for staining fat cells, but also to quantitate fat cells in culture plates of 10T1/2 cells and 3T3-L1 cells. Experiments with AD showed suppression of adipogenesis up to $1 \mu \mathrm{M}$ and non-suppression of adipogenesis at $10 \mu \mathrm{M}$ concentration. At $10 \mu \mathrm{M}$ concentration of $\mathrm{AD}$, there were adipogenesis and myogenesis. Normally, when myogenesis was favored, adipogenesis was suppressed by strong androgens $\mathrm{T}$ and DHT (21). However, at $10 \mu \mathrm{M}$ of AD, we observed both myogenesis and adipogenesis, as confirmed by adipocyte staining and immunohistochemical staining of myotubes. This observation was not consistent with the reciprocity observed between adipogenesis and myogenesis by strong androgens (T, DHT) in C3H10T1/2 cells [20]. However, this in vitro effect of AD on adipogenesis correlated nicely with the key in vivo observation, that administration of AD (1500 mg/day) to hypogonadal men increased muscle mass, but did not decrease whole body fat mass. Similarly the in-vitro results of strong androgen T on myogenesis and adipogenesis [20] correlated 
well with the in-vivo results of clinical trials of strong androgen T [1]-[4].

Another key observation of the clinical trial of $A D$ was an increase in estrone and estradiol level after $A D$ administration. So in the in-vitro experiment there was a need to use aromatase inhibitor (AI) to inhibit aromatase activity so that $\mathrm{AD}$ was not converted to estrone or estradiol, which might be supporting adipogenesis. But, co-incbuation of AD with $\mathrm{AI}$ in C3H10T1/2 cells did not alter (neither decrease nor increase) adipogenesis or myogenesis indicating that estrogen had no role in adipognesis in 10T1/2 cells. In fact direct addition of estrogen $\left(E_{2}\right)$ to $10 \mathrm{~T} 1 / 2$ cells did not show any increase in adipogenesis over the untreated control cells. So, the effect of $\mathrm{AD}$ on adipogenesis was the direct action of AD. Hence, the increase in adipocytes at high concentration of $\mathrm{AD}$ was also due to the direct action of AD. This in-vitro effect of AD on adipogenesis correlated significantly with an example found in nature. In spotted hyenas, AD level is higher in females than in males [27]. These female animals are bigger and more aggressive than the male animals. So, large size and aggressive behavior of the females are due to the high level of AD. In fact, testosterone level is not high in female hyenas [27] [28].

AD suppressed adipogenesis up to $1 \mu \mathrm{M}$ concentration, but at $10 \mu \mathrm{M}$ concentration $\mathrm{AD}$ failed to suppress adipogenesis in C3H10T1/2 cells. Hence, we carried out adipogenic experiments with another adipogenic cell line (3T3-L1). Adipogenic quantitation assay with 3T3-L1 preadipocytes showed a similar pattern of adiopgenesis, inhibition at $1 \mu \mathrm{M}$ and then reversal back to control level at $10 \mu \mathrm{M}$ concentration of $\mathrm{AD}$, thus indicating that this biphasic effect on adipogenesis was an inherent biological action of $\mathrm{AD}$ and not a spurious effect of $\mathrm{AD}$ in C3H10T1/2 cells. This observation raised the question whether this was a unique biological action of AD in C3H10T1/2 cells or a common biological action of weak androgen in C3H10T1/2 cells. So we carried out adipogenic experiment with another weak androgen DHEA in 10T1/2 cells. Adipogenesis with DHEA also showed the same pattern of suppression up to $1 \mu \mathrm{M}$ and then reversal back to control level of adipogenesis at $10 \mu \mathrm{M}$ concentration, indicating it was a common biological effect of weak androgens on adipogenesis.

\section{Conclusion}

In conclusion, weak androgen $\mathrm{AD}$ behaves like strong androgen testosterone with respect to myogenesis. But with respect to adipogenesis, it is weak and less effective than testosterone. This difference on adipogenesis might be a physiological difference between strong androgens like T, DHT and weak androgens like AD, DHEA. Based on AD biphasic regulation of adipogenesis and experiments with bicalutamide, it was indicated that $\mathrm{AD}$ biological action was mediated through AR. So, the nature of AD binding to AR might be responsible for this differential biological effect. It is appropriate here to point out that AD has a partial agonist/antagonist nature of binding to AR as reported by Chen et al. [23] based on cell transcription assays. Hence, the physiological difference on adipogenesis could be due to the nature (partial agonist/antagonist) of AD binding to AR. The future strategy for unraveling this mystery is to check the specific effects of $A D$ on molecular mechanisms of myogenesis and adipogenesis in C3H10T1/2 and 3T3-L1 cell lines.

\section{Acknowledgements}

This work was supported by a start-up research grant (grant \# 261-200-889) from KCOM to P.R. Technical assistance in preparation of the manuscript and bibliographical help by Sujatha Bhuvanaraj is duly acknowledged. Help with statistical analysis by Dr. Dilli Bhatta from Department of Mathematics, Truman State University, Kirksville, MO is gratefully acknowledged.

\section{References}

[1] Snyder, P.J., Peachey, H., Hannoush, P., Berlin, J.A., Loh, L., Lenrow, D.A., Holmes, J.H., Dlewati, A., Santanna, J., Rosen, C.J. and Strom, B.L. (1999) Effect of Testosterone Treatment on Body Composition and Muscle Strength in Men over 65 Years of Age. The Journal of Clinical Endocrinology and Metabolism, 84, 2647-2653.

[2] Bhasin, S., Storer, T.W., Berman, N., Callegari, C., Clevenger, B.A., Philips, J., Bunnell, T., Tricker, R., Shirazi, A. and Casaburi, R. (1996) The Effects of Supraphysiologic Doses of Testosterone on Muscle Size and Strength in Normal Men. The New England Journal of Medicine, 335, 1-7. http://dx.doi.org/10.1056/NEJM199607043350101

[3] Bhasin, S., Woodhouse, L., Casaburi, R., Singh, A.B., Bhasin, D., Berman, N., Chen, X.H., Yarasheski, K.E., Magliano, L., Dzekov, C., Dzekov, J., Bross, R., Philips, J., Sinha-Hikim, I., Shen, R.Q. and Storer, T.W. (2001) Testosterone Dose-Response Relationships in Healthy Young Men. American Journal of Physiology_Endocrinology and Metabolism, 281, E1172-E1181. 
[4] Bhasin, S., Woodhouse, L. and Storer, T.W. (2001) Proof of the Effect of Testosterone on Skeletal Muscle. Journal of Endocrinology, 170, 27-38. http://dx.doi.org/10.1677/joe.0.1700027

[5] Katznelson, L., Rosenthal, D.I., Rosol, M.S., Anderson, E.J., Hayden, D.L., Schoenfeld, D.A. and Klibanski, A. (1998) Using Quantitative CT to Assess Adipose Distribution in Adult Men with Acquired Hypogonadism. American Journal of Roentgenology, 170, 423-427. http://dx.doi.org/10.2214/ajr.170.2.9456958

[6] Bhasin, S., Storer, T.W., Berman, N., Yarasheski, K.E., Philips, J., Clevenger, B., Lee, W.P., Bunnell, T.J. and Casaburi, R. (1997) Testossterone Replacement Increases Fat-Free Mass and Muscle Size in Hypogonadal Men. The Journal of Clinical Endocrinology and Metabolism, 82, 407-413.

[7] Brodsky, I.G., Balagopal, P. and Nair, K.S. (1996) Effects of Testosterone Replacement on Muscle Mass and Muscl Protein Synthesis in Hypogonadal Men-A Clinical Research Center Study. The Journal of Clinical Endocrinology and Metabolism, 81, 3469-3475.

[8] Snyder, P.J., Peachey, H., Berlin, J.A., Hannoush, P., Haddad, G., Dlewati, A., Santanna, J., Loh, L., Lenrow, D.A., Holmews, J.H., Kapoor, S.C., Atkinson, L.E. and Strom, B.L. (2000) Effects of Testosterone Replacement in Hypogonadal Men. The Journal of Clinical Endocrinology and Metabolism, 85, 2670-2677.

[9] Wang, C., Swerdloff, R.S., Iranmanesh, A., Dobs, A., Snyder, P.J., Cunningham, G., Matsumoto, A.M., Weber, T., Berman, N. and Testosterone Gel Study Group (2000) Transdermal Testosterone Gel Improves Sexual Function, Mood, Muscle Strength and Body Composition Parameters in Hypogonadal Men. The Journal of Clinical Endocrinology and Metabolism, 85, 2839-2853.

[10] Sinha-Hikim, I., Artaza, J.N., Woodhouse, L., Gonzalez-Cadavid, N., Singh, A.B., Lee, M.I., Storer, T.W., Casaburi, R., Shen, R.Q. and Bhasin, S. (2002) Testosterone-Induced Increase in Muscle Size in Healthy Men is Associated with Muscle Fiber Hypertrophy. The American Journal of Physiology: Endocrinology and Metabolism, 283, E154-E164.

[11] Wilson, J.D. (1988) Androgen Abuse by Athletes. Endocrine Reviews, 9, 181-199. http://dx.doi.org/10.1210/edrv-9-2-181

[12] Cowan, D.A. and Kicman, A.T. (1997) Doping in Sport and Society: Misuse, Analytical Tests and Legal Aspects. Clinical Chemistry, 43, 1261-1279.

[13] Blaquier, J., Forchielli, E. and Dorfman, R.I. (1967) In Vitro Metabolism of Androgens in Whole Human Blood. Acta Endocrinologica, 55, 697-704.

[14] Mahesh, V.B. and Greenblatt, R.B. (1962) The in Vivo Conversion of Dehydroepiandrosterone and Androstenedione to Testosterone in Humans. European Journal of Endocrinology, 41, 400-406.

[15] Morales, A.J., Nolan, J.J., Nelson, J.C. and Yen, S.S.C. (1994) Effects of Replacement Dose of Dehydroepiandrosterone in Men and Women of Advanced Age. The Journal of Clinical Endocrinology \& Metabolism, 78, 1360-1367.

[16] http://www.deadiversion.usdoj.gov/fed regs/rules/2005/fr1216.htm

[17] Jasuja, R., Ramaraj, P., Mac, R.P., Singh, A.B., Storer, T.W., Artaza, J.N., Miller, A., Singh, R., Taylor, W.E., Lee, M.L., Davidson, T., Sinha-Hikim, I., Gonzalez-Cadavid, N. and Bhasin, S. (2005) $\Delta$-4-Androstene-3,17-Dione Binds Androgen Receptor, Promotes Myogenesis in Vitro and Increases Serum Testosterone Levels, Fat-Free Mass, and Muscle Strength in Hypogonadal Men. The Journal of Clinical Endocrinology \& Metabolism, 90, 855-863. http://dx.doi.org/10.1210/jc.2004-1577

[18] Lassar, A.B., Peterson, B.M. and Weintraub, H. (1986) Transfection of a DNA Locus That Mediates the Conversion of 10T1/2 Fibroblasts to Myoblasts. Cell, 47, 649-656. http://dx.doi.org/10.1016/0092-8674(86)90507-6

[19] Fischer, L., Boland, G. and Tuan, R.S. (2002) Wnt-3 A Enhances Bone Morphogenic Protein-2-Mediated Chondrogenesis of Murine C3H10T1/2 Mesenchymal Cells. Journal of Biological Chemistry, 277, 30870-30878. http://dx.doi.org/10.1074/jbc.M109330200

[20] Singh, R., Artaza, J.N., Taylor, W.E., Gonzalez-Cadavid, N.F. and Bhasin, S. (2003) Androgens Stimulate Myogenic Differentiation and Inhibit Adipogenesis in $\mathrm{C}_{3} \mathrm{H}_{10} \mathrm{~T}_{1 / 2}$ Pluripotent Cells through an Androgen Receptor-Mediated Pathway. Endocrinology, 144, 5081-5088. http://dx.doi.org/10.1210/en.2003-0741

[21] Singh, R., Artaza, J.N., Taylor, W.E., Braga, M., Yum, X., Gonzalez-Cadavid, N. and Bhasin, S. (2006) Testosterone Inhibits Adipogenic Differentiation in 3T3-L1 Cells; Nuclear Translocation of Androgen Receptor Complex with $\beta$-Catenin and T-Cell Factor 4 May Bypass Canonical Wnt Signaling to Down-Regulate Adipogenic Transcription Factors. Endocrinology, 147, 141-154. http://dx.doi.org/10.1210/en.2004-1649

[22] Bennet, C.N., Ross, S.E., Longo, K.A., Bajnok, L., Hemati, N., Johnson, K.W., Harrison, S.D. and MacDougald, O.A. (2002) Regulation of Wnt Signaling during Adipogenesis. Journal of Biological Chemistry, 277, 30998-31004. http://dx.doi.org/10.1074/jbc.M204527200

[23] Chen, F., Knecht, K., Leu, C., Rutledge, S.J., Scafonas, A., Gambone, C., Vogel, R., Zhang, H., Kasparcova, V., Bai, C., Harada, S., Schmidt, A., Reszka, A. and Freedman, L. (2004) Partial Agonist/Antagonist Properties of Androstenedione and 4-Androsten-3 $\beta, 17 \beta$-Diol. The Journal of Steroid Biochemistry and Molecular Biology, 91, 247-257. http://dx.doi.org/10.1016/j.jsbmb.2004.04.009 
[24] Soto, A.M. and Sonnenschein, C. (1987) Cell Proliferation of Estrogen-Sensitive Cells: The Case for Negative Control. Endocrine Reviews, 8, 44-52. http://dx.doi.org/10.1210/edrv-8-1-44

[25] Sonnenschein, C., Olea, N., Pasanen, M.E. and Soto, M.E. (1989) Negative Control of Cell Proliferation: Human Prostate Cancer Cell and Androgens. Cancer Research, 49, 3473-3481.

[26] Launoit, Y., Veilleus, R., Dufour, M., Simrad, J. and Labrie, F. (1991) Characteristics of the Biphasic Action of Androgens and of the Potent Antiproliferative Effects of the New Pure Anti-Estrogen EM-139 on Cell Cycle Kinetic Parameters in LNCaP Human Prostatic Cancer Cells. Cancer Research, 51, 5165-5170.

[27] Glickman, S.E., Frank, L.G., Davidson, J.M., Smith, E.R. and Siteri, P.K. (1987) Androstenedione May Organize or Activate Sex-Reversed Traits in Female Spotted Hyenas. Proceedings of the National Academy of Sciences of the United States of America, 84, 3444-3447. http://dx.doi.org/10.1073/pnas.84.10.3444

[28] Kurk, H. (1972) The Spotted Hyena. University of Chicago Press, Chicago, 1-335.

\section{Abbreviations}

AD-Androstrostenedione

ECL-Enhanced chemiluminescence

AM-Adipogenic medium

GM-Growth medium

AR-Androgen receptor

MHCII-Myosin heavy chain II

AI-Aromatase inhibitor

PVDF-Polyvinylidene fluoride

BIC-Bicalutamide

RT-PCR - Reverse transcribed - Polymerase chain

$\mathrm{C} / \mathrm{EBP} \alpha-\mathrm{CCAAT} /$ Enhancer-Binding reaction Protein alpha

SDS-PAGE_-Sodium dodecyl sulfate-polyacrylamide gel electrophoresis

DHT-Dihydrotestosterone

DHEA-Dehydroepiandrosterone

$\mathrm{T}$-Testosterone

$\mathrm{E}_{2}$-Estradiol 
Scientific Research Publishing (SCIRP) is one of the largest Open Access journal publishers. It is currently publishing more than 200 open access, online, peer-reviewed journals covering a wide range of academic disciplines. SCIRP serves the worldwide academic communities and contributes to the progress and application of science with its publication.

Other selected journals from SCIRP are listed as below. Submit your manuscript to us via either submit@scirp.org or Online Submission Portal.
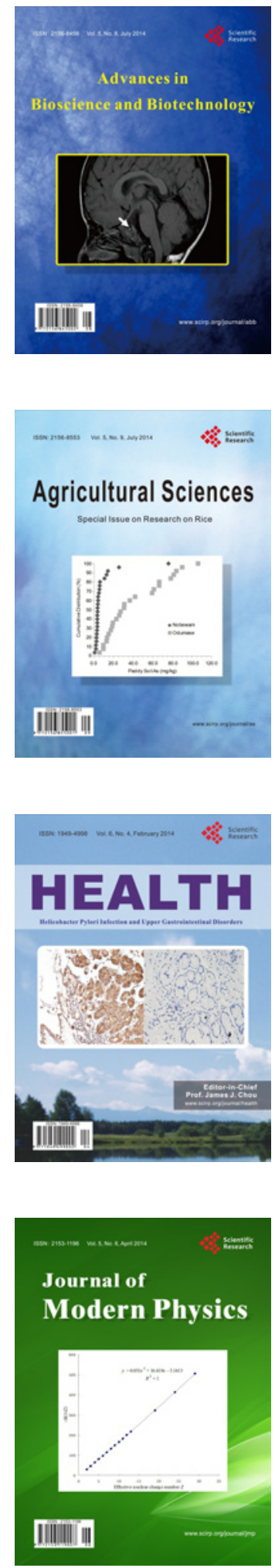
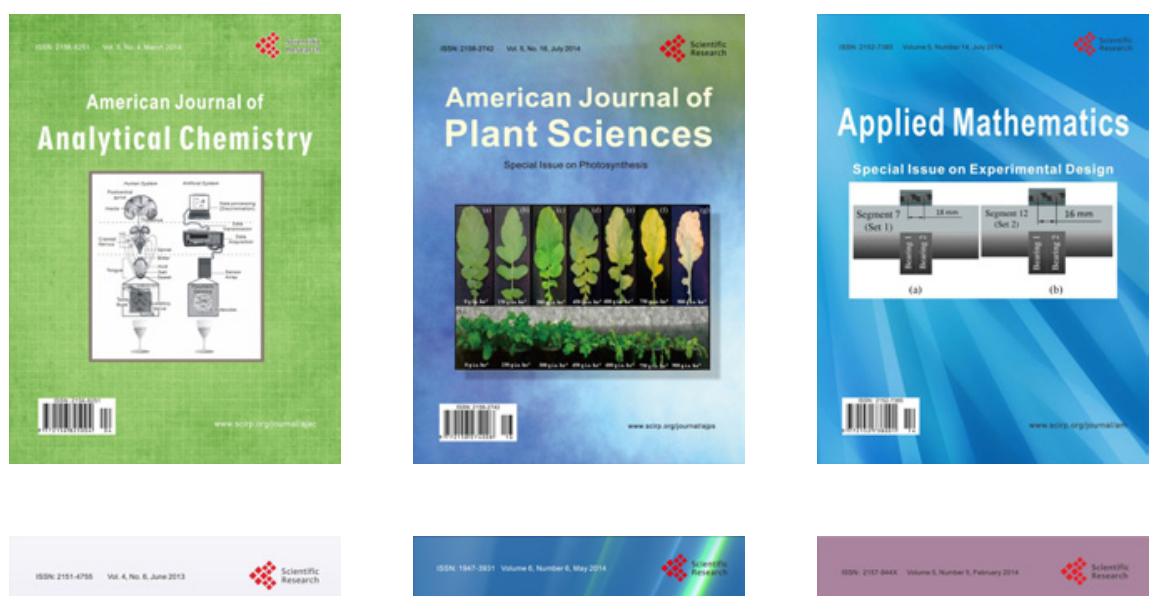

Creative Education
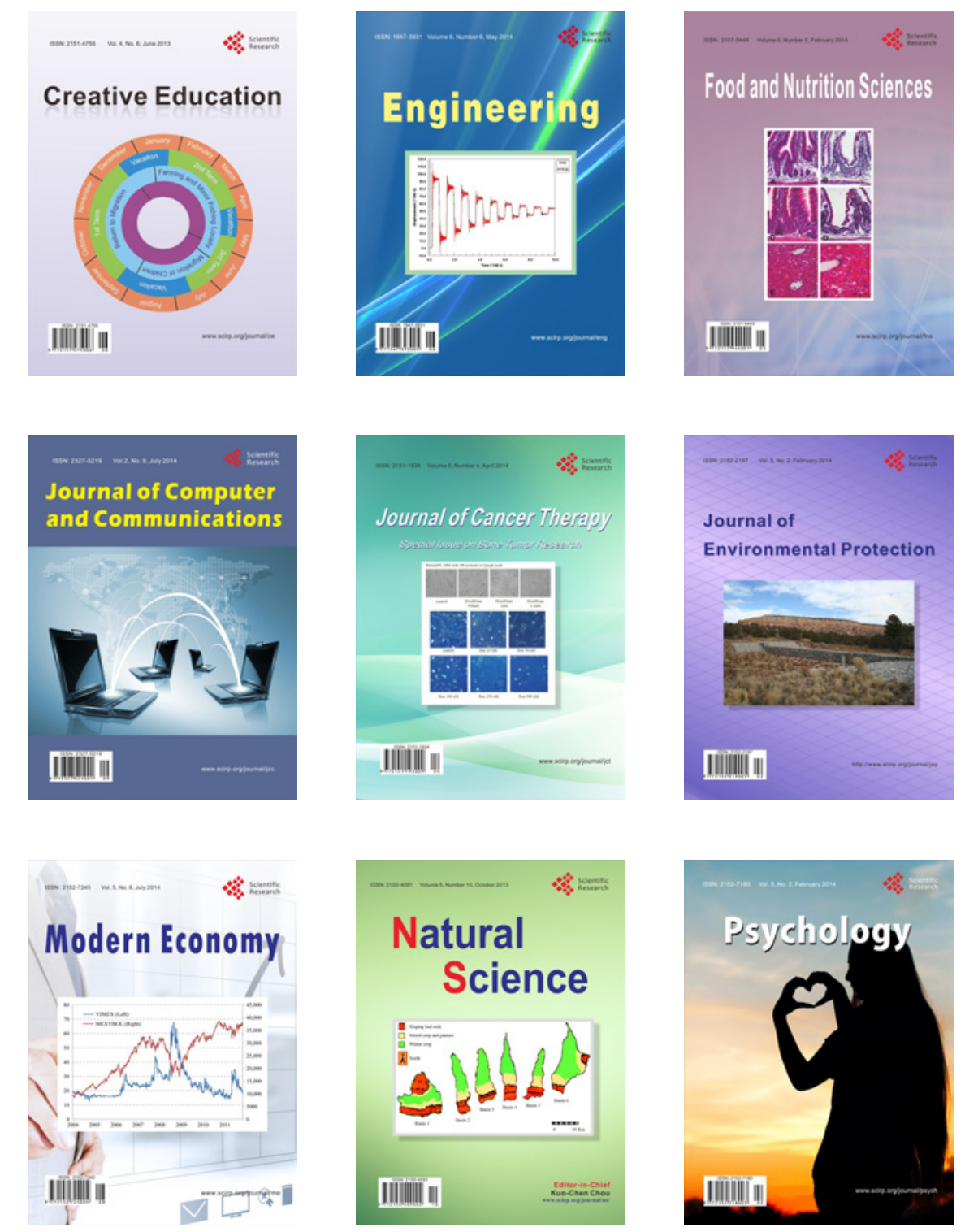